\title{
Angular Photometry of Biological Tissue by Ellipsoidal Reflector Method
}

\author{
M.A. Bezuglyi, N.V. Bezuglaya, A.V. Ventsuryk, K.P. Vonsevych \\ National Technical University of Ukraine «Igor Sikorsky Kyiv Polytechnic Institute», \\ Peremohy Ave., 37, Kyiv 03056, Ukraine
}

Received 01.02.2019

Accepted for publication 29.05.2019

\begin{abstract}
Angular measurements in optics of biological tissues are used for different applied spectroscopic task for roughness surface control, define of refractive index and for research of optical properties. Purpose of the research is investigation of the reflectance of biologic tissues by the ellipsoidal reflector method under the variable angle of the incident radiation.

The research investigates functional features of improved photometry method by ellipsoidal reflectors. The photometric setup with mirror ellipsoid of revolution in reflected light was developed. Theoretical foundations of the design of an ellipsoidal reflector with a specific slot to ensure the input of laser radiation into the object area were presented. Analytical solution for calculating the angles range of incident radiation depending on the eccentricity and focal parameter of the ellipsoid are obtained. Also created the scheme of image processing at angular photometry by ellipsoidal reflector.

The research represents results of experimental series for samples of muscle tissues at wavelengths $405 \mathrm{~nm}, 532 \mathrm{~nm}, 650 \mathrm{~nm}$. During experiment there were received photometric images on the equipment with such parameters: laser beam incident angles range $12.5-62.5^{\circ}$, ellipsoidal reflector eccentricity 0.6 , focal parameter $18 \mathrm{~mm}$, slot width $8 \mathrm{~mm}$.

The nature of light scattering by muscle tissues at different wavelengths was represented by graphs for the collimated reflection area. The investigated method allows qualitative estimation of influence of internal or surface layers of biologic tissues optical properties on the light scattering under variable angles of incident radiation by the shape of zone of incident light.
\end{abstract}

Keywords: ellipsoidal reflector, angular measurements, optical properties, muscle tissue.

DOI: $10.21122 / 2220-9506-2019-10-2-160-168$

\begin{tabular}{|c|c|}
\hline $\begin{array}{l}\text { Адрес для переписки: } \\
\text { М.А. Безугльий } \\
\text { Национальный технический университет Украины «Киевский } \\
\text { политехнический институт», } \\
\text { пр. Победыl, 37, г. Киев 03056, Украина } \\
\text { e-mail: mikhail_bezuglyу@ukr.net }\end{array}$ & $\begin{array}{l}\text { Address for correspondence: } \\
\text { M.A. Bezuglyi } \\
\text { National Technical University of Ukraine «Igor Sikorsky Kyiv } \\
\text { Polytechnic Institute», } \\
\text { Peremohy Ave., 37, Kiev03056, Ukraine } \\
\text { e-mail: mikhail_bezuglyy@ukr.net }\end{array}$ \\
\hline $\begin{array}{l}\text { Для цитирования: } \\
\text { M.A. Bezuglyi, N.V. Bezuglaya, A.V. Ventsuryk, K.P. Vonsevych. } \\
\text { Angular Photometry of Biological Tissue by Ellipsoidal Reflector } \\
\text { Method. } \\
\text { Приборы и методы измерений. } \\
\text { 2019. - Т. 10, № 2. - С. 160-168. } \\
\text { DOI: } 10.21122 / 2220-9506-2019-10-2-160-168\end{array}$ & $\begin{array}{l}\text { For citation: } \\
\text { M.A. Bezuglyi, N.V. Bezuglaya, A.V. Ventsuryk, K.P. Vonsevych. } \\
\text { Angular Photometry of Biological Tissue by Ellipsoidal Reflector } \\
\text { Method. } \\
\text { Devices and Methods of Measurements. } \\
\text { 2019, vol. 10, no. 2, pp. 160-168. } \\
\text { DOI: } 10.21122 / 2220-9506-2019-10-2-160-168\end{array}$ \\
\hline
\end{tabular}




\title{
Угловая фотометрия биологических тканей методом эллипсоидальных рефлекторов
}

\author{
М.А. Безуглый, Н.В. Безуглая, А.В. Венцурик, К.П. Вонсевич \\ Национальный технический университет Украинь \\ «Киевский политехнический институт имени Игоря Сикорского», \\ пр. Победы, 37, г. Киев 03056, Украина
}

Поступила 01.02.2019

Принята к печати 29.05.2019

Угловые измерения в оптике биологических тканей широко применяются для решения различных прикладных спектроскопических задач для контроля шероховатой поверхности, определения показателя преломления, а также для изучения оптических свойств. Целью данной работы являлось исследование отражающей способности биологических тканей методом зеркальных эллипсоидов вращения при переменных углах падения зондирующего изучения.

В работе исследуются функциональные возможности усовершенствованного метода фотометрии эллипсоидальными рефлекторами. Разработана и представлена установка для фотометрии зеркальным эллипсоидом вращения в отраженном свете. Для обеспечения работы метода представлены теоретические основы конструирования эллипсоидального рефлектора с характерным пазом для обеспечения ввода лазерного излучения в исследуемую область. Получены аналитические выражения для вычисления диапазона углов падающего излучения в зависимости от эксцентриситета и фокального параметра эллипсоида. Также представлена усовершенствованная схема обработки изображений, получаемых при угловой фотометрии эллипсоидальными рефлекторами.

Представлены результаты серии экспериментальных исследований для мышечной ткани на длинах волн 405 нм, 532 нм и 650 нм. В ходе эксперимента были получены фотометрические изображения при использовании фотометра со следующими конструктивными параметрами: диапазон угла падения лазерного излучения $12.5-62.5^{\circ}$, эксцентриситет эллипсоидального рефлектора 0,6 , фокальный параметр 18 мм и ширина паза 8 мм.

Характер светорассеяния мышечными тканями на различных длинах волн представлен графиками для зоны коллимированного отражения. При этом форма зоны падающего потока позволяет оценить влияние оптических свойств внутреннего или приповерхностного слоя биологической тканине на светорассеяние при различных углах падения.

Ключевые слова: эллипсоидальный рефлектор, угловые измерения, оптические свойства, мышечная ткань.

DOI: $10.21122 / 2220-9506-2019-10-2-160-168$

\begin{tabular}{|c|c|}
\hline $\begin{array}{l}\text { Адрес для переписки: } \\
\text { М.А. Безугльй } \\
\text { Национальный технический университет Украины «Киевский } \\
\text { политехнический институт», } \\
\text { пр.Победыл, 37, г.Киев 03056, Украина } \\
\text { e-mail: mikhail_bezuglyy@ukr.net }\end{array}$ & $\begin{array}{l}\text { Address for correspondence: } \\
\text { M.A. Bezuglyi } \\
\text { National Technical University of Ukraine «Igor Sikorsky Kyiv } \\
\text { Polytechnic Institute», } \\
\text { Peremohy_Ave., 37, Kiev03056,_Ukraine } \\
\text { e-mail: mikhail_bezuglyy@ukr.net }\end{array}$ \\
\hline Для цитирования: & For citation: \\
\hline M.A. Bezuglyi, N.V. Bezuglaya, A.V. Ventsuryk, K.P. Vonsevych. & M.A. Bezuglyi, N.V. Bezuglaya, A.V. Ventsuryk, K.P. Vonsevych. \\
\hline Angular Photometry of Biological Tissue by Ellipsoidal Reflector & Angular Photometry of Biological Tissue by Ellipsoidal Reflector \\
\hline Method. & Method. \\
\hline Приборы и методы измерений. & Devices and Methods of Measurements. \\
\hline 2019. - T. 10, № 2. - C. 160-168. & 2019 , vol. 10 , no. 2 , pp. $160-168$. \\
\hline DOI: $10.21122 / 2220-9506-2019-10-2-160-168$ & DOI: $10.21122 / 2220-9506-2019-10-2-160-168$ \\
\hline
\end{tabular}




\section{Introduction}

The progress in laser and computer technologies allow implementing of optical methods in different areas of non-destructive control. Among other, such methods applies for investigation of dispersive mediums, materials, and coating [1-5], or diagnostics of tissues and organs condition in biology and medicine [6-12].

Distribution of the electromagnetic radiation along optical range in biologic tissues (BT) is complicated and stochastic processes. Such distribution defines analytically by the classic electromagnetic theory, or extrapolates by the radiative transfer theory $[13,14]$. Mathematical solution of subordinated to such theories systems of equations performs by the variety of theoretic and numeric methods [15]. Despite of that, the unified system of received results comparison criterion is still not established. Typical reasons are significant limitations of features of measuring and computation instruments intended for determination of indexes and coefficients of equations.

Full-wave simulation like finite different time domain $[16,17]$ or finite element method $[18,19]$ applies more often for rigorous solution of Maxwell's equations. However, it is still perspective for practical application in optics of biological tissues. In biomedical optics the radiative transfer theory is more popular. It provides results that are more precise and corresponds to reliability criteria in clinical application during investigation of pathologies. For direct and inverse problem solution following methods are typical: Monte Carlo simulation, adding-doubling method, Kubelka-Munk function, diffusion approximation, and other. Direct problem solution is determination of transmittance, reflectance and absorption of the BT, while inverse is determination of the BT optical properties - absorption and scattering coefficients, anisotropy factor.

Continuing investigation of features and properties of optical electronic devices, which uses ellipsoidal reflectors (ER) as the optical core of informational and measuring system of biomedical photometer [20-22], the current report represents results of series of practical experiments. These results allow investigating additional information about the interaction of electromagnetic radiation with turbid biological media according to the light scattering optics.
The document represents investigation of biological tissues by methods of light scattering optics in experimental conditions in vitro or ex vivo. In the research there were set hypotheses and limitations for proper introduction of measured values into mathematical model. The layer of tissue under investigation contains top and bottom boundaries, and internal region. The thickness of internal region is small relatively to its perimeter. BT surface (the boundary between the media) usually have roughness of different size comparing to wavelength. In such case, the external specular and/or diffuse reflection from it is possible. There occurs scattering inside the BT during the passing of light beam through the surface. Such process occurs until the total absorption, or appearing of light beam outside of the sample in the form of internal diffuse reflection or transmission. The main goal of such experiment is minimizing of external component impact (especially diffuse) on the resulting spatial distribution of scattered light. Such conditions can be created experimentally by several ways:

- put the sample of BT between glass elements with polished surfaces [23-25] with the sizes of fine irregularities less than the radiation wavelength

- creation of physiologic experiment conditions by placing of the sample inside the physiologic liquids [26].

Experiment under in vivo conditions involve thick (semi-infinite) biologic sample under investigation. The light flux, registered in opposite to incident radiation direction, consist of a passed through the surface and interacted with the media part, and a reflected by the surface light. The nature of angular distribution of reflected flux defines the type of the surface and its relief [27]. The probability of light diffusion backward to the surface depends on the quantity of interactions with the media, when the photon direction changes before the moment of its absorption in scattering, and depends on the optical properties of BT [22]. Model experiment in both cases satisfies considering Fresnel conditions.

Light scattering by BT samples depends on the illumination type and have significant differences during application of diffuse or collimated flux. There apply different measuring standards for determination of reflective ability and reflection coefficient for these light methods [28]. Reflectance and the reflection coefficient depends 
on the incidence angle, radiation polarization, and refractive index. These parameters determine the boundary between the two media. Refractive index and optical properties of media significantly depends from the wavelength. Optical properties of BT can be determined in the indirect method only. Thus, the measurement of the refractive index should be performed only experimentally. For many types of tissues, the problem is in the absorption and scattering. Thus, the reflection coefficient for skin equals to $10-55 \%$ and depends on the radiation spectrum, pigmentation rate and rugosity, presence of adipose and moisture. Mentioned factors depend on the gender, age, type, and color of the skin [29].

Considering the mentioned information, the purpose of the research is investigation of the reflectance of biologic tissues by the ellipsoidal reflector method under the variable angle of the incident radiation.

\section{Methods and tools}

The research focused on specific features of realization of improved method of photometry by ellipsoidal reflectors. The target is investigation of its use for measurements of reflected and backscattered light. The method allows investigating of the optical properties of scattered media under different incident angles, and energy characteristics of incident optical radiation. For research of the method the experimental unit was constructed (Figure 1). The unit use photometric system with ellipsoid of revolution with internal mirror surface. The mirror is truncated by the focal planes orthogonally to the semi-major axis and contains specific longitudinal slot (Figure 2) for receiving of optical radiation under variable angles. Ellipsoidal reflector was produced by the method of trajectory copying [30]. Additionally, authors investigated other technologies of shape formation of internal ellipsoidal mirror surface [31] and photometer production [22].

The unit contain mechanism for micrometric height regulation for investigation of $\mathrm{BT}$ with various thicknesses. Experimental unit operates by the method of photometry in reflected light [20]. The condition of semi-infinite thickness of BT sample satisfies by the application of black opaque lining with absorption coefficient close to 0.99 .

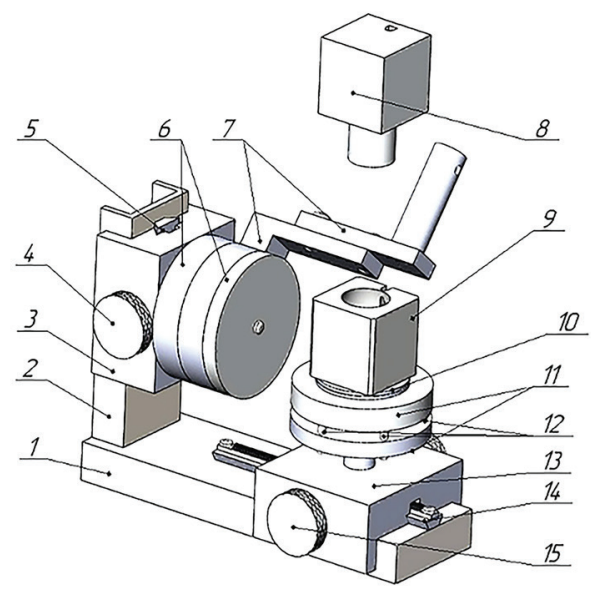

Figure 1-Scheme of unit for angular photometry by ellipsoidal reflector: 1-base; 2 -bar; 3 -height regulation mechanism; 4-flywheel; 5-worm gear with dovetail; 6-cap disc; 7 - laser module; 8-CCD camera; 9-ellipsoidal reflector; 10 -biological tissue holder; 11 -subject stage; 12 -adjustment screws; 13 -horizontal regulation block; 14 -worm gear with dovetail; 15 - flywheel

The adjustment device aligns reflector, optical system, and CCD camera referring to horizontal baseline. The change of energetic characteristics of incident radiation performs by regulation of power by universal power source, which further supplies to laser diodes with the wavelength $405 \mathrm{~nm}$, $532 \mathrm{~nm}$, and $650 \mathrm{~nm}$. The nominal power of each diode equal to $5 \mathrm{~mW}$. Unit consists of base 1 with fitted perpendicular to it bar 2. To this bar attached the height regulation mechanism 3 . It is worm gear with dovetail 5 , and is actuated by the flywheel 4 .
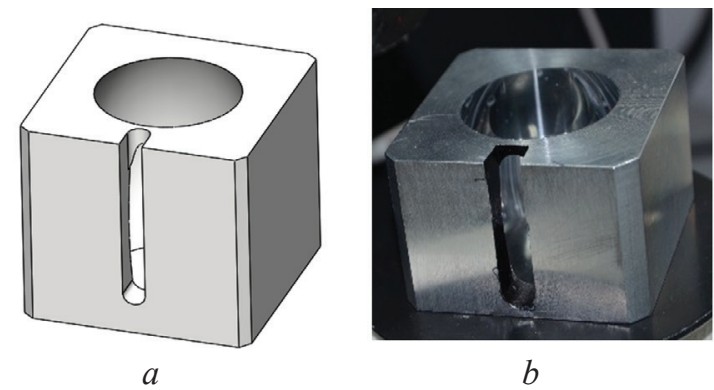

Figure 2 - Ellipsoidal reflector for angular photometry: 3D model $(a)$; end-product $(b)$

Mechanism 3 consists of three disks, one of which is a cap 6 for fixing of all disks, and two others acts as a fastening for laser module 7 . The aperture in the bottom part of the module applies for ensuring of necessary laser beam diameter. In the experimental unit it equals to $1 \mathrm{~mm}$. In addition, 
stand have subject stage 11 , which is fastened to the horizontal regulation block 13 by worm gear and dovetail 14. Longitudinal displacement performs during rotation of flywheel 15. Subject stage fits horizontally, and precise regulation performs by adjustment screws 12 . The measuring base of the stand is ellipsoidal reflector 9, which is mounted on the BT holder 10 during experiment. The unit adjustment performs before measurements for ensuring of horizontal mounting of subject stage, sample, and reflector. The height of laser block regulates for variable thickness of BT sample. In the holder installs reflector 9 align with CCD camera 8 for ellipsoidal CCD-reflectometry [20]. Images are registered under different incident angles of laser beam and analyzed by specialized software.

Considering axial symmetry of vertically oriented ellipsoid of revolution, the determination of operating range of incident angles performs with using of ellipse equation:

$$
\frac{x^{2}}{a^{2}}+\frac{z^{2}}{b^{2}}=1
$$

where $a$ and $b$ - semi-minor and semi-major axis of ellipse.

Considering expression of ellipse through its eccentricity $e$, focal parameter $p$ and focal distance $f$, it is possible to determine the points of its intersection with straight lines, which contains ultimate points of critical angles (Figure 3):

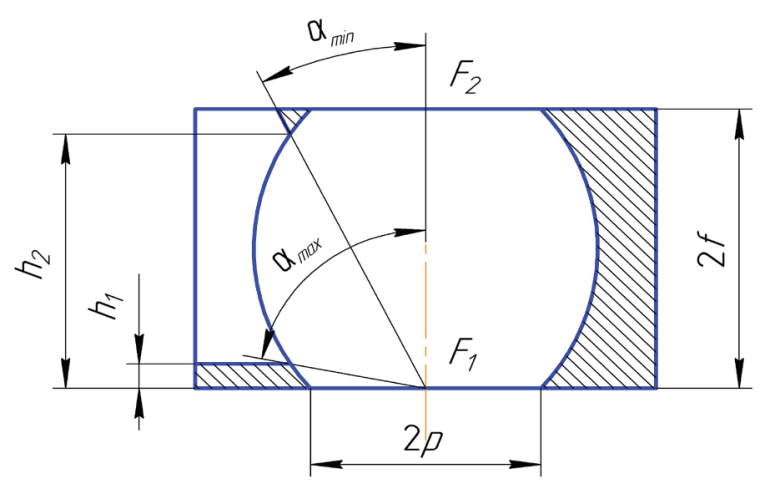

Figure 3 - Determination of critical angles of incident light in ellipsoidal reflector with slot

$$
\begin{aligned}
& x_{1}=\sqrt{\frac{p^{2}}{\left(1-e^{2}\right)}-\left(1-e^{2}\right) \cdot\left(f-h_{1}\right)^{2}}, \\
& x_{2}=\sqrt{\frac{p^{2}}{\left(1-e^{2}\right)}-\left(1-e^{2}\right) \cdot\left(h_{2}-f\right)^{2}} .
\end{aligned}
$$

Considering (1), critical angles of incident radiation for ellipsoidal reflector with its set of constructive parameters can be determined using equations:

$$
\begin{aligned}
& \alpha_{\text {min }}=\operatorname{arcctg}\left(\frac{h_{2}}{x_{2}}\right), \\
& \alpha_{\text {max }}=\operatorname{arcctg}\left(\frac{h_{1}}{x_{1}}\right) .
\end{aligned}
$$

It is important to note that the coordinate $x_{2}$ determines the value of minimum angle in case of slant height for top slot forming part (Figure 3). If slant height is parallel to the axis $x$ (Figure 2), the minimum angle determines from the simple trigonometric dependency.

Equations (2) are valid for lines, which contains optical axis of incident ray. During the calculation of critical incident angles there considers radius of real laser beam and increase minimal and decrease maximal angles correspondingly.

Heights $h_{1}$ and $h_{2}$ are technological dimensions and are selected for ensuring of ER shape support depending on the detail production material. For current investigation it was used construction alloy ENAW-2024; and heights $h_{1}$ and $\left(f-h_{1}\right)$ were selected in the range $2-4 \mathrm{~mm}$.

Based on the mechanism of image processing at ellipsoidal photometry [32], the methodology of photometric image analysis during angular photometry by ellipsoidal reflector was improved. The processing scheme (Figure 4), except of region of interest and external ring $A 1$, also contains ellipse of incident flux $A 2$ and area of collimated reflection $A 3$.

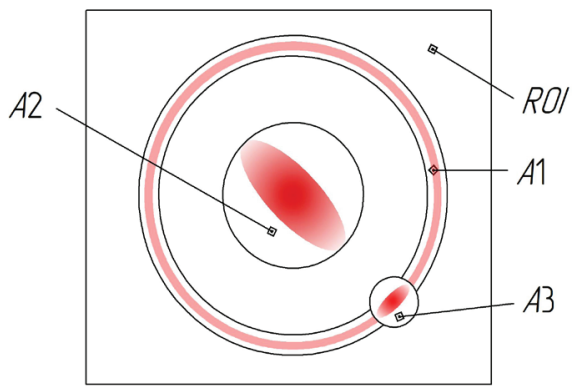

Figure 4 - The processing scheme of photometric images during angular photometry by ellipsoidal reflectors: $R O I$ - region of interest; $A 1$ - external ring; $A 2$ - ellipse of incident flux; $A 3$ - area of collimated reflection

The characteristic value for radiation flux distribution in each region of analysis is relative illuminance of the zone EA. It calculates as the ratio of total pixel brightness $I_{p i x}$ to the area of corresponding zone: 


$$
E_{A}=\frac{I_{p i x}}{A} .
$$

The area of the zone can be expressed by metric value as in $[17,22]$ or can be represented by total sum of pixels, which forms corresponding zone.

\section{Result and discussion}

As the object for investigation it was selected the muscle tissues of porcine (Type 1) and chicken (Type 2) of various thickness, optical properties (Table) of which were determined similarly [20]. The tissue was separated perpendicularly to muscle tissues for providing of minimal divergences of anisotropy factor [33]. Further samples were preserved under normal conditions in $0.9 \%$ solution of $\mathrm{NaCl}$ during $30 \mathrm{~min}$.

The angular photometry by ellipsoidal reflector results (Figure 1) contain groups of photometric images (Figures 5,6) for three wavelengths under different incident angles with the step $2.5^{\circ}$.

Table

\section{Optical properties}

\begin{tabular}{lcccc}
\hline $\begin{array}{l}\text { Muscle tissue } \\
\text { optical properties }\end{array}$ & $\lambda, \mathrm{nm}$ & $\mu_{a}$ & $\mu_{s}$ & $g$ \\
\hline \multirow{3}{*}{ Type 1 } & 405 & $2.06 \pm 0.08$ & $49.5 \pm 3.5$ & $0.964 \pm 0.012$ \\
& 532 & $1.93 \pm 0.1$ & $61.4 \pm 4.9$ & $0.966 \pm 0.012$ \\
& 650 & $1.88 \pm 0.2$ & $41.8 \pm 4.7$ & $0.973 \pm 0.009$ \\
Type 2 & 405 & $1.01 \pm 0.04$ & $124.1 \pm 10.2$ & $0.958 \pm 0.01$ \\
& 532 & $0.74 \pm 0.22$ & $186.1 \pm 12.6$ & $0.958 \pm 0.012$ \\
& 650 & $0.78 \pm 0.1$ & $216.7 \pm 16.1$ & $0.965 \pm 0.019$ \\
\hline
\end{tabular}

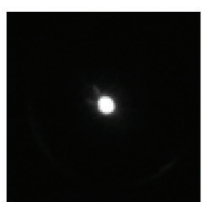

$a$

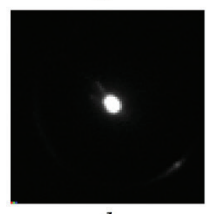

$d$

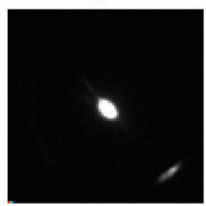

$g$

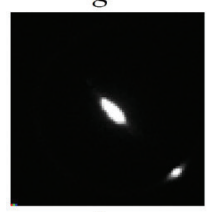

$k$

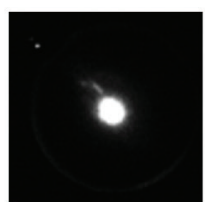

b
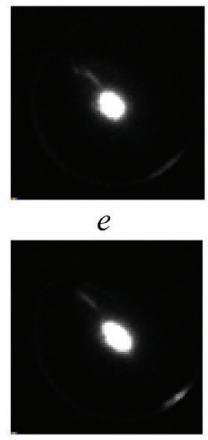

$h$

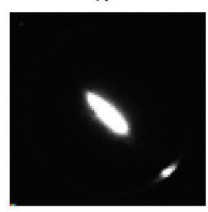

$m$

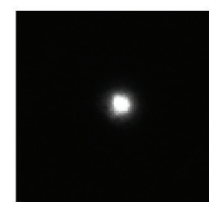

c

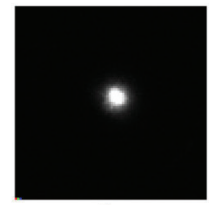

f
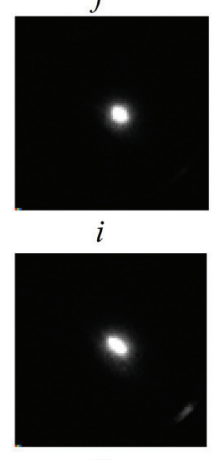

$n$

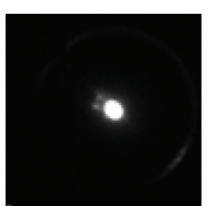

$a$

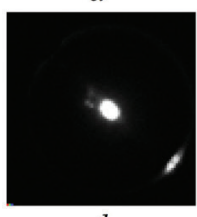

$d$

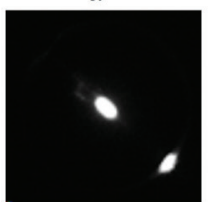

$g$

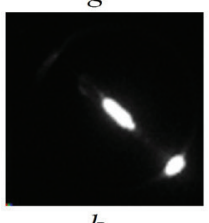

$k$

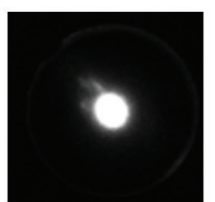

b

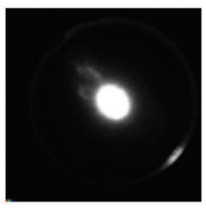

e

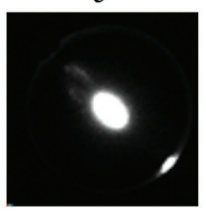

h

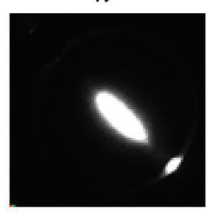

m

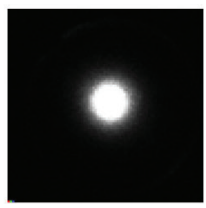

c

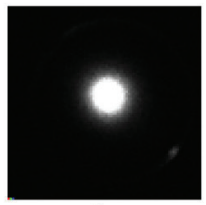

f

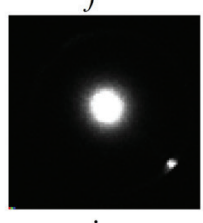

$i$

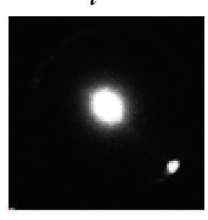

n
Figure 5-Photometric images of backscattered light by Type 1 muscle tissue samples with the thickness $4.8 \pm 0.21 \mathrm{~mm}$ at the wavelength $405 \mathrm{~nm}(a, d, g, k)$, $532 \mathrm{~nm}(b, e, h, m), 650 \mathrm{~nm}(c, f, i, n)$ under incident angles of laser beam: $30^{\circ}(a, b, c), 40^{\circ}(d, e, f), 50^{\circ}(g, h, i)$, $60^{\circ}(k, m, n)$ correspondingly
Figure 6-Photometric images of backscattered light by Type 2 muscle tissue samples with the thickness $4.6 \pm 0.27 \mathrm{~mm}$ at the wavelength $405 \mathrm{~nm}(a, d, g, k)$, $532 \mathrm{~nm}(b, e, h, m), 650 \mathrm{~nm}(c, f, i, n)$ under incident angles of laser beam: $30^{\circ}(a, b, c), 40^{\circ}(d, e, f), 50^{\circ}(g, h, i)$, $60^{\circ}(k, m, n)$ correspondingly 
For the applied ellipsoidal reflector parameters (eccentricity $e=0.6$, focal parameter $p=18 \mathrm{~mm}$, and focal distance $f=16.5 \mathrm{~mm}$ ) and laser beam of diameter $1 \mathrm{~mm}$, the operational range of angle of incident ray equals to $12.5-62.5^{\circ}$.

Based on the received images for both samples of muscle tissues (porcine and chicken) at the wavelength 405 and $532 \mathrm{~nm}$, the dynamic change of incident flux ellipse shape performs according to laws of geometric optics for reflecting surface. At the same time, the shape of spot of incident flux at the wavelength of $650 \mathrm{~nm}$ is close to elliptic only for big incident angles. This fact explains the dependency of backscattered radiation more from the optical properties (Table) inside the tissue itself then from the surface properties and sub-surface layers.

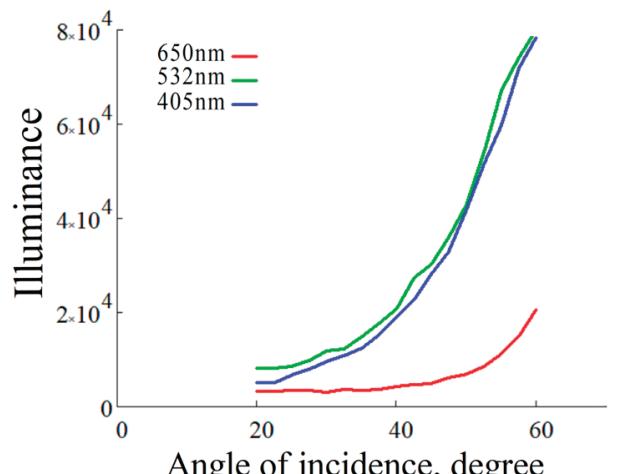

$a$

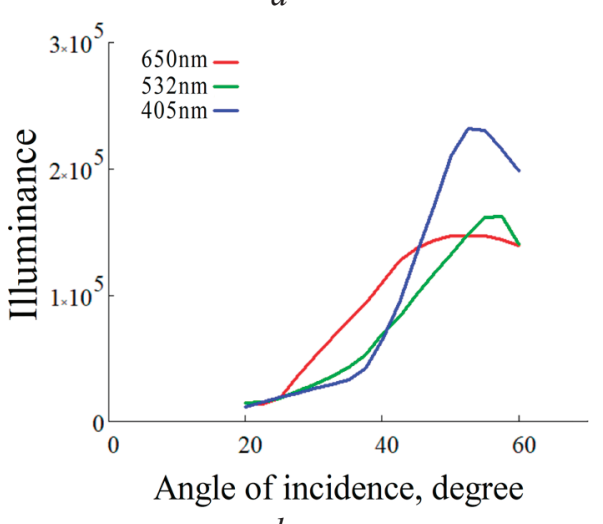

b

Figure 7 - Illuminance of area of collimated reflection for Type $1(a)$ and Type $2(b)$ samples of muscle tissues for wavelength $405 \mathrm{~nm}$ (blue line), $532 \mathrm{~nm}$ (green line), and $650 \mathrm{~nm}$ (red line)

Analysis of Figure $7 a$ represent that collimated reflection at the wavelength $650 \mathrm{~nm}$ generate smaller illuminance of corresponding zone for Type 1 muscle tissue under all investigated angles of incident light. From the other side, the illuminance of the same zone for the chicken muscle tissue samples is significantly bigger comparing to illuminance on the wavelengths
$405 \mathrm{~nm}$ and $532 \mathrm{~nm}$ in the range of incident angles $20-40^{\circ}$. Graphs for Type 2 tissues with the increasing of incidence angle continues to grow with different acceleration until reaching of definite angle. After increasing of that angle there occurs decline with different velocity. Authors explain this by the reaching of specific "critical" angle, under which in the ellipsoidal reflector there observes doubled reflection from the opposite side. Due to slot presence on this side, the radiation leaves the measuring core of photometer with ER. The absence of mentioned peak of illuminance for porcine muscle tissue indicates that it possibly present in the incident angles, which exceeds the working range of angles for mounted mirror ellipsoid of revolution (Figure 2). At the same time, characteristic view of graphs for both tissues proofs the relative interconnection between optical properties of muscle tissues in the defined wavelengths [7]. Note that in the current research there are specified results of angular photometry for thick muscle tissue samples. The efficiency of application of ellipsoidal reflector was proved only for maximum consolidation of reflected collimated flux. However, experiments proved the same efficiency for the sample thickness less than $1 \mathrm{~mm}$. Also, we can receive the useful information from the component of external ring $A 2$.

\section{Conclusion}

The specificities of angular photometry by ellipsoidal reflectors was investigated in the current research. Experiments was done for samples of both type of muscle tissue at wavelengths $405 \mathrm{~nm}$, $532 \mathrm{~nm}$, and $650 \mathrm{~nm}$. The investigated method allows qualitative estimation of influence of internal or surface layers of biologic tissues optical properties on the light scattering under variable angles of incident radiation by the shape of zone of incident light. Illuminance of collimated reflection area for various wavelengths mutually correlates with the optical properties of biologic tissues. The determination of properties of such correlation refers to the creation of adequate interaction model of optical radiation with layers of biologic tissues, and boundaries of its distribution with correct consideration of parameters of laser radiation and incident angle.

\section{References}

1. Ghabara T. Study of the emissivity of rough surfaces periodic using the method of coupled waves 
analysis (CWA) compared with method of geometrical optics approximation (GOA). Natural Science, 2011, no.3(01), pp. 57-64. DOI: 10.4236/ns.2011.31008

2. Nazarov Yu.F., Shkilko A.M., Tihonenko V.V., Kompaneec I.V. [Metals and alloys surface roughness investigation and control methods]. Zhurnal fiziki $i$ inzhenerii poverhnosti [Journal of surface physics and engineering], 2007, no. 3-4(5), pp. 207-216 (in Russian).

3. Szewczenko J., Szewczenko J., Jaglarz J., Basiaga M., Kurzyk J., Paszenda Z. Optical methods applied in thickness and topography testing of passive layers on implantable titanium alloys. Optica Applicata, 2013, no. 1(43), pp. 173-180. DOI: $10.5277 /$ oa130121

4. Feidenhans'1 N.A., Hansen P.E., Pilny L., Madsen M.H., Bissacco G., Petersen J.C., Taboryski R.J. Comparison of optical methods for surface roughness characterization. Measurement Science and Technology, 2015, no. 8(26), pp. 085208 .

DOI: $10.1088 / 0957-0233 / 26 / 8 / 085208$

5. Svitasheva S.N. Experimental Study of Polarization Properties of Rough Surface. Electrical and Electronic Engineering, 2012, no. 2(6), pp. 403-408.

DOI: $10.5923 /$ j.eee. 20120206.10

6. Tuchin V.V. Opticheskaya biomeditsinskaya diagnostika v 2-h tomah. [Optical biomedical diagnostics, In 2 parts. Part. 1]. Translated from English, Moscow: Physmathlit, 2007, 560 p.

7. Bashkatov A.N., Genina E.A., Tuchin V.V. Chapter 5. Tissue Optical Properties in Handbook of Biomedical Optics. Taylor \& Francis Group, LLC, CRC Press Inc., 2011, 37 p.

8. Tuan Vo-Dinh. Biomedical Photonics Handbook II Vol. USA: CRC Press LLC, 2003, 889 p.

9. Genina E. Metody biofotoniki. Fototerapiya [Methods of biophotonics: Phototherapy]. Saratov: Novyi Veter Publ., 2012, 119 p.

10. Litvinova K.S., Rafailov I.E., Dunaev A.V., Sokolovski S.G., Rafailov E.U. Non-invasive biomedical research and diagnostics enabled by innovative compact lasers. Progress in Quantum Electronics, 2017, vol. 56, pp. 1-14. DOI: $10.1016 /$ j.pquantelec.2017.10.001

11. Rogatkin D.A., Lapaeva L.G. Prospects for Development of Noninvasive Spectrophotometric Medical Diagnosis. Biomedical Engineering, 2003, no. 4(37), pp. 217-222.

DOI: 10.1023/B:BIEN.0000003304.00591.e7

12. Rogatkin D.A., Lapaeva L.G., Bychenkov O.A., Tereshchenko S.G., Shumskii V.I. Principal sources of errors in noninvasive medical spectrophotometry. Part 1. Physicotechnical sources and factors of errors. Measurement Techniques, 2013, no. 2(56), pp. $201-210$.

13. Liemert A., Kienle A. Comparison between radiative transfer theory and the simplified spherical harmonics approximation for a semi-infinite geometry.
Optics Letters, 2011, vol. 36, pp. 4041-4043.

DOI: $10.1364 /$ OL.36.004041

14. Gantria M., Trabelsib H., Bensalahb R., Sedikia E. Solution of a Radiative Transfer Problem in a Biological Tissue. An Optical Tomography Model. Proceedings of AIP Conference Proceedings 935, 237, 2007. DOI: https://doi.org/10.1063/1.2795420

15. Pavlov S., Kozlovska T., Vaselenko V. Optykoelektronni zasoby diagnostuvannia patologii liudyny, povyazanyh iz peryferychnym krovoobigom. Monografiia [Optoelectronic devices for the diagnosis of human pathologies associated with peripheral circulation: Monography]. Vinnytsia: VNTU, 2014, 140 p.

16. Zhao Y., Argyropoulos Ch., Hao Ya. Fullwave finite-difference time-domain simulation of electromagnetic cloaking structures. Optics Express, 2008, no. 16(9), pp. 6717-6730.

DOI: $10.1364 /$ OE.16.006717

17. Karagounis G., De Zutter D., Vande Ginste D. Full-wave simulation of optical waveguides via truncation in the method of moments using PML absorbing boundary conditions. Opt. Express, 2016, no. 24(25), pp. 28326 28336. DOI:10.1364/OE.24.028326

18. Lu Yu, Tian Ji., Cong W., Wang Ge, Yang W., Qin Ch., Xu M. Spectrally resolved bioluminescence tomography with adaptive finite element analysis: methodology and simulation. Physics in Medicine and Biology, 2007, no. 52(15), pp. 4497-4512.

DOI: $10.1088 / 0031-9155 / 52 / 15 / 009$

19. Lapeer R.J., Gassona P.D., Karri V. Simulating plastic surgery: from human skin tensile tests, through hyperelastic finite element models to real-time haptics. Progress in Biophysics and Molecular Biology, 2010, no. 103(2-3), pp. 208-216.

DOI: $10.1016 /$ j.pbiomolbio.2010.09.013

20. Bezuglaya N.V., Bezuglyi M.A., Chmyr Yu.V. Spatial fluxing biometry of environments by ellipsoidal reflectors. Electronics and Communications, 2014, no. 83(6), pp. 87-93. (in Ukrainian)

21. Bezuglyi M., Bezuglaya N., Viruchenko A. On the possibility of ellipsoidal photometry and Monte Carlo simulation to spatial analysis of biological media. Proceedings of Electronics and nanotechnology ELNANO-2017, 2017, pp. 321-325.

DOI: $10.1109 /$ ELNANO.2017.7939771

22. Bezuglyi M.A., Bezuglaya N.V., Helich I.V. Ray tracing in ellipsoidal reflectors for optical biometry of media. Appl Opt., 2017, no. 56(30), pp. 8520-8526.

DOI: $10.1364 / \mathrm{AO} .56 .008520$

23. Passos D., Hebden J.C., Pinto P.N., Guerra R. Tissue phantom for optical diagnostics based on a suspension of microspheres with a fractal size distribution. Biomed. Opt., 2005, no. 10, pp. 1-11.

DOI: $10.1117 / 1.2139971$ 
24. Jacques S.L. Optical properties of biological tissues: a review. Phys. Med. Biol., 2013, no. 58, pp. R37R61. DOI: 10.1088/0031-9155/58/11/R37

25. Hall G., Jacques S.L., Eliceiri K.W., Campagnola P.J. Goniometric measurements of thick tissue using Monte Carlo simulations to obtain the single scattering anisotropy coefficient. Biomedical optics express, 2012, no. 3(11), pp. 2707-2719.

DOI: $10.1364 /$ BOE.3.002707

26. Robkamp D., Truffer F., Bolay S., Geiser M. Forward scattering measurement device with a high angular resolution. Optics express, 2007, no. 5, pp. 26832690. DOI: $10.1117 / 1.2139971$

27. Volz Hans G. Hans Industrial Color Testing: Fundamentals and Techniques. 2nd Edition. Wiley-VCH; 2nd Completely Revised edition, 2002, 388 p.

28. Horibe T., Ishii K., Fukutomi D., Awazu K. Influence of diffuse reflectance measurement accuracy on the scattering coefficient in determination of optical properties with integrating sphere optics (a secondary publication). Laser Ther, 2015, vol. 24, no. 4, pp. 303-310. DOI: 10.5978 /islsm.15-OR-19
29. Vo-Dinh T. Biomedical Photonics Handbook II Vol. USA: CRC Press LLC, 2003, 300 p.

30. Ivanov Yu.S., Monsar O.A., Sinyavskyi I.I. Vygotovlennia glybokoi asferyky traektornym kopiiuvanniam ta ii zastosuvannia. [Fabrication deep aspheric by trajectory copying and its applying]. Bulletin of NTUU “KPI”. Series instrument making, 2004, no. 28, pp. 24-28 (in Ukrainian).

31. Bezuglyi M.A., Linucheva O.V., Bezuglaya N.V., Byk M.V., Kostiuk S.A. Kontrol formy elipsoidalnyh reflektoriv biomedychnyh fotometriv [Control of the ellipsoidal reflectors shape for biomedical photometers]. Research Bulletin of NTUU “KPI", 2017, vol. 53, no. 1, pp. 62-69 (in Ukrainian).

32. Bezuglyi M., Bezuglaya N., Kuprii O., Yakovenko I. The non-invasive optical glucometer prototype with ellipsoidal reflectors. Proc. in IEEE, 2018, pp. 1-4.

DOI: $10.1109 /$ RTUCON.2018.8659864

33. Bezuglaya N.V., Bezuglyi M.A. Spatial Photometry of Scattered Radiation by Biological Objects. Proc. SPIE, 2013, no. 9032-15, pp. Q1-Q5.

DOI: $10.1117 / 12.2044609$ 